\title{
Biological activities of basil essential oil: a review of the current evidence
}

\author{
A tividades biológicas do óleo essencial de manjericão: uma revisão das evidências atuais \\ Actividades biológicas del aceite esencial de albahaca: una revisión de la evidencia actual
}

Received: 09/09/2021 | Reviewed: 09/17/2021 | Accept: 09/22/2021| Published: 09/24/2021

\author{
Mayara Zagoto \\ ORCID: https://orcid.org/0000-0002-9676-7622 \\ State University of Maringá, Brazil \\ E-mail: mayara_zagotto@hotmail.com \\ Gabriel Fernando Esteves Cardia \\ ORCID: https://orcid.org/0000-0003-3781-7498 \\ State University of Maringá, Brazil \\ E-mail: g_cardia@hotmail.com \\ Edvalkia Magna Teobaldo da Rocha \\ ORCID: https://orcid.org/0000-0003-3011-9849 \\ State University of Maringá, Brazil \\ E-mail:pg401988@uem.br \\ Kathia Socorro Mathias Mourão \\ ORCID: https://orcid.org/0000-0002-9598-0253 \\ State University of Maringá, Brazil \\ E-mail: ksmmourao@gmail.com \\ Vanderly Janeiro \\ ORCID: https://orcid.org/0000-0001-8804-6107 \\ State University of Maringá, Brazil \\ E-mail: vjaneiro@uem.br \\ Roberto Kenji Nakamura Cuman \\ ORCID: https://orcid.org/0000-0002-4906-887X \\ State University of Maringá, Brazil \\ E-mail: rkncuman@uem.br \\ Adriana Aparecida Pinto \\ ORCID: https://orcid.org/0000-0003-1727-9581 \\ State University of Maringá, Brazil \\ E-mail: aapinto@uem.br \\ Robinson Luiz Contiero \\ ORCID: https://orcid.org/0000-0003-4197-3813 \\ State University of Maringá, Brazil \\ E-mail: rcontiero@gmail.com \\ Paulo Sérgio Lourenço de Freitas \\ ORCID: https://orcid.org/0000-0001-6663-2797 \\ State University of Maringá, Brazil \\ E-mail: pslfreitas@uem.br
}

\begin{abstract}
Currently, natural products are being used as a therapeutic alternative in the treatment and prevention of several diseases due to their low toxicity and relevant pharmacological potential. Thus, we can highlight basil (Ocimum basilicum L), one of the most used aromatic plants worldwide. Therefore, we provide some current evidence and insight into the potential therapeutic effect of basil essential oil to expand the available knowledge. A narrative review was carried out by searching electronic databases, providing a comprehensive analysis of the literature, where it was possible to identify existing problems and gaps to facilitate future research on basil essential oil. The available literature on basil essential oil presents us with several important pharmacological activities, such as: antioxidant, antiviral, antimicrobial, analgesic, anti-inflammatory, and analgesic and diuretic properties, among others. However, further research must be carried out to increase knowledge about this plant with enormous potential and determine its effectiveness and use in clinical conditions.
\end{abstract}

Keywords: Ocimum basilicum L.; Essential oils; Therapeutic potentials; Biological properties.

\section{Resumo}

Atualmente os produtos naturais vêm sendo utilizado como alternativa terapêutica no tratamento e na prevenção de diversas doenças, devido à sua baixa toxicidade e relevante potencial farmacológico. Desta forma, podemos destacar o manjericão (Ocimum basilicum L), uma das plantas aromáticas mais utilizadas em todo o mundo. Portanto, fornecemos algumas evidências atuais e uma visão do potencial efeito terapêutico do óleo essencial de manjericão para expandir o conhecimento disponível. Uma revisão narrativa foi realizada por meio de busca em bases de dados 
eletrônicas, proporcionando uma análise abrangente da literatura, onde foi possível identificar os problemas e lacunas existentes para facilitar futuras pesquisas sobre o óleo essencial de manjericão. A literatura disponível sobre o óleo essencial de manjericão nos apresenta várias atividades farmacológicas importantes, como: antioxidante, antiviral, antimicrobiana, analgésica, anti-inflamatória, e propriedades analgésicas, diuréticas, entre outras. No entanto, novas pesquisas devem ser realizadas para aumentar o conhecimento sobre esta planta com enorme potencial, e determinar a sua eficácia e utilização em condições clinicas.

Palavras-chave: Ocimum basilicum L; Óleos essenciais; Potencial terapêutico; Propriedades biológicas.

\section{Resumen}

Actualmente, los productos naturales se están utilizando como alternativa terapéutica en el tratamiento y prevención de diversas enfermedades, debido a su baja toxicidad y relevante potencial farmacológico. Así, podemos destacar la albahaca (Ocimum basilicum L), una de las plantas aromáticas más utilizadas a nivel mundial. Por lo tanto, proporcionamos algunas pruebas y conocimientos actuales sobre el posible efecto terapéutico del aceite esencial de albahaca para ampliar el conocimiento disponible. Se llevó a cabo una revisión narrativa mediante la búsqueda de bases de datos electrónicas, proporcionando un análisis completo de la literatura, donde fue posible identificar los problemas y lagunas existentes para facilitar la investigación futura sobre el aceite esencial de albahaca. La literatura disponible sobre el aceite esencial de albahaca nos presenta varias actividades farmacológicas importantes, tales como: propiedades antioxidantes, antivirales, antimicrobianas, analgésicas, antiinflamatorias, analgésicas y diuréticas, entre otras. Sin embargo, se deben realizar más investigaciones para aumentar el conocimiento sobre esta planta con un enorme potencial, y para determinar su efectividad y uso en condiciones clínicas.

Palabras clave: Ocimum basilicum L; Aceites esenciales; Potenciales terapéuticos; Propiedades biológicas.

\section{Introduction}

Currently, natural products are being used as a therapeutic alternative in the treatment and prevention of several diseases due to their low toxicity and relevant pharmacological potential. Many medicinal plants are considered an essential source for the extraction of essential oils, which have several important biological activities and can be used to treat various pathologies (Gautam \& Jachak, 2009; Thomford et al., 2018).

Essential oils usually have a complex composition, with terpenes and phenylpropanoids being the main compounds found, and have been widely used in folk medicine and the food, cosmetics, and perfume industries (Bakkali et al., 2008; Reichling et al., 2009). Thus, we can highlight basil (Ocimum basilicum L), one of the most used aromatic plants worldwide. Belonging to the Lamiaceae family and is typically cultivated in Mediterranean areas and semitropical and tropical regions of America, Asia, and Africa (Nazir et al., 2020; Sahoo et al., 1997). The essential oils of the Lamiaceae family stand out for having several medicinal properties (Cardia et al., 2018, 2021; Karpiński, 2020; Uritu et al., 2018).

Basil essential oil exhibits a wide variety of chemical compounds, rich in monoterpenoids, sesquiterpenoids, and flavonoids. However, there is a wide variation in the composition of basil essential oil due to several factors, such as weather conditions, harvest time and extraction method, species, and parts used (Clements \& Treble, 1999; Topalov \& Topalov, 1962). In addition, the classification of plants that make up the genus of basil is complex, due to natural and artificial crossings, which resulted in a great genetic variation, morphology and chemistry of the plant and its essential oils (Paton et al., 1999; Putievsky et al., 1999). Thus, the chemical composition of the oil can vary greatly, influencing the biological activity of the plant according to its major constituents. However, one of the main constituents reported for basil essential oil is linalool, and other compounds are also frequent, such as estragole, 1,8-cineole and eugenol (Marotti et al., 1996).

Basil essential oil has been widely used in the perfumery, cooking, the food industry, and the production of cosmetics and medicines (Duke, 2001). Traditionally, basil is used as a condiment in the food industry. However, several studies have revealed that its action goes beyond the concept of spice due to its pharmacological properties, such as: antioxidant, antiviral, antimicrobial, analgesic, anti-inflammatory, and analgesic properties, diuretics, among others (Bilal et al., 2012; Ch et al., 2015). It has been widely used in traditional medicine to treat anxiety, diabetes, cardiovascular disease, and headache (Bora et al., 2011). 
Therefore, we provide some current evidence and insight into the potential therapeutic effect of basil essential oil to expand the available knowledge and guide future research.

\section{Methodology}

A narrative review was carried out through a search in electronic databases, providing a comprehensive analysis of the literature, where it was possible to identify existing problems and gaps to facilitate future research on the topic (Sant'Anna Ramos Vosgerau \& Paulin Romanowski, 2014). Relevant articles were selected from a search from January/2021 to June/2021 in four electronic databases (PubMed, Scopus, Web of Science, and Google Scholar), using the following descriptors: Essential oil and Basil or Essential oil and Ocimum basilicum. The titles and abstracts of the articles found were evaluated. Relevant publications were read in their entirety and independently by the authors, analyzed, and included in this review (Estrela, 2018).

\section{Results and Discussion}

\section{Basil essential oil}

Essential oils are natural products resulting from secondary metabolites found in plants, consisting mainly of terpenoid compounds, and obtained from different parts of the plant and extraction methods. Currently, essential oils are indicated in the literature for numerous uses, including in the food and cosmetics industry, pharmaceutical industry and natural therapies to treat various diseases (Abdel-Kader et al., 2019; Bakkali et al., 2008). Thus, essential oils in treating diseases can be a great alternative due to their low cost and few reported adverse effects. In this sense, basil essential oil stands out. Because it has a pleasant aroma, it is considered an excellent compound with applications in various food, cosmetics and aromatherapy industries. Furthermore, several studies have demonstrated basil's different biological activities, indicating its use in alternative medicine (Bilal et al., 2012; Bora et al., 2011; Ch et al., 2015; D. Singh \& Chaudhuri, 2018). So much so that there is a forecast that the Ocimum species essential oil market will grow by around 200 million dollars by 2023 (Gurav et al., 2021 ).

\section{Food and cosmetic industry}

With a wide variety of medicinal and culinary plants, some species, such as basil, have attracted much interest. These plants can be used for various purposes. In addition to being used as spices to improve the flavour of foods, they are used both in raw materials and in preparations, due to the antioxidant effects and health benefits already reported in the literature. Due to its antioxidant capacity, several aromatic plants are used in the food industry as food additives (Pawar et al., 2014; Yuan et al., 2016). Basil is an aromatic herb widely used for its characteristic aroma in cooking for hundreds of years worldwide in salads, tomato-based dishes, pasta sauces, and perfumery. In addition, basil is a component of several dietary supplements, which are easily accessible as products capable of maintaining and promoting health (Berg et al., 2011; Bower et al., 2016).

Thus, the large consumption of basil as a food ingredient makes it a possible candidate for biofortification purposes (Kiferle et al., 2019). Currently, several studies have demonstrated the use of basil essential oil in foods as an antioxidant in meat and dairy products, antibacterial in sausages, antifungal in links, and several other applications (Falowo et al., 2019; Gaio et al., 2015; Kocić-Tanackov et al., 2020; Licon et al., 2020).

\section{Anti-inflammatory and Antioxidant Activity}

Currently, there is great interest in anti-inflammatory compounds and natural antioxidants found in medicinal plants that can help prevent and treat various diseases. Several studies describe the antioxidant and anti-inflammatory activities present in basil essential oils (Araújo Couto et al., 2019; Pandey et al., 2016). Basil oil has been found to have anti- 
inflammatory and anti-edematogenic activity in models of inflammation by blocking the cyclooxygenase and lipoxygenase pathways (S. Singh et al., 1996). Furthermore, another study demonstrated the anti-inflammatory activity of basil essential oil and suggested that this effect could be due to the inhibition of cyclooxygenase 2 caused by its constituents (Złotek et al., 2016).

In addition, a study demonstrated the antioxidant activity of basil essential oil from three different harvest regions and concluded that the oil with the highest eugenol content was the one with the highest antioxidant activity (Ahmed et al., 2019). Likewise, another study also compared different varieties of basil essential oil that had a similar chemical composition, and all showed antioxidant activity, mainly due to the presence of several constituents with proven antioxidant activity (Koroch et al., 2017). Treatment with basil essential oil in encapsulated form also demonstrated antioxidant activity from the DPPH sequestering activity assay (Sundararajan et al., 2018).

Additionally, a basil-based preparation demonstrated an antioxidant, increasing glutathione peroxidase, glutathione reductase, superoxide dismutase, and catalase, and decreasing the level of lipid peroxidation in an acute liver injury model (Dwivedi et al., 2015). Furthermore, Stanojevic et al. also described basil essential oil's antimicrobial and antioxidant activity, demonstrating a free radical scavenging activity and suggesting it as a good alternative for application in the pharmaceutical and cosmetic industries (Stanojevic et al., 2017).

Basil essential oil has been shown to have a cardioprotective activity capable of protecting the myocardium against isoproterenol-induced infarction, mainly due to antioxidant activities (Fathiazad et al., 2012). Furthermore, crude basil extract decreased the blood pressure level in rats in a dose-dependent manner (Umar et al., 2010). Probably, this cardioprotective activity of basil may be related to its ability to eliminate ROS (Kaurinovic et al., 2011). Thus, compounds extracted from natural sources, such as basil essential oil, capable of protecting against oxidative and inflammatory damage, can have several applications in preventing and treating diseases. Therefore, we can see that the essential oil of basil has considerable potential. However, more research should be explored in this context.

\section{Antifungal and antimicrobial activities of basil}

Fungal infections remain a serious problem around the world that requires effective therapeutic strategies. Basil essential oil has traditionally been used to treat bacterial and fungal infections (Miao et al., 2020). The antimicrobial activities of basil were evaluated against S. aureus, E. coli, B. subtilis, and Pasteurella multocida. Also, against pathogenic fungi such as A. niger, Mucor mucedo, Candida albicans, Alternaria alternata, Alternaria tenuissima, Aspergillus fumigatus, Fusarium solani, Botryodiplodia theobromae, and R. solani, the results obtained showed that basil has antimicrobial activity against all tested microorganisms (Ahmad et al., 2016; Hussain et al., 2008; Marco et al., 2020; Tavallali et al., 2019). Furthermore, other studies have also demonstrated the antimicrobial activity of basil against various bacteria, yeasts, and fungi (Kaya et al., 2008; Sunčica et al., 2011).

Several essential oils are well recognized in the literature due to their antimicrobial activities, and the same occurs with Basil. Beatović and collaborators tested several basil essential oils against a panel of selected Gram-positive and Gramnegative bacteria, as well as fungi, and all the oils tested exhibited significant antibacterial activity against the investigated bacterial species, further confirming the antimicrobial potential of the essential oil of basil (Beatović et al., 2015). However, despite demonstrating a very significant antimicrobial activity, this activity may vary according to the composition of the essential oil and the method used. A study using basil diluted in agar was not shown to be a potent antimicrobial (Runyoro et al., 2010).

When tested against multiresistant bacterial strains, such as Staphylococcus, Pseudomonas, and Enterococcus, basil oil showed an inhibitory activity (Opalchenova \& Obreshkova, 2003). Furthermore, as already well reported in the literature, the antimicrobial activity of basil essential oil may be similar to some commercial antibiotics. A study compared the 
antimicrobial activity of basil essential oil with ciprofloxacin and gentamicin in 10 different bacterial strains and showed a strong inhibitory effect (Stanojevic et al., 2019). Basil essential oil is composed of several constituents that have antimicrobial activity, so its activity may be due to a synergistic action of its constituents. Thus, the variation in the composition of the essential oil of basil can hinder the possibility of bacterial resistance arising (Jugreet \& Mahomoodally, 2020; Yap et al., 2014). Thus, we can suggest that further investigations should be carried out to determine which basil essential oil composition has a more efficient antimicrobial activity.

\section{Antiviral activity}

Basil has also shown vast antiviral activity and can be used to treat a variety of viral diseases, such as eye, respiratory and liver infections. Due to the lack of effective drugs to treat adenoviral infections, the essential oil, and its isolated constituents can be potential therapeutic agents for treating these diseases (Chiang et al., 2005; Ryu et al., 1992). In addition, recently, a molecular anchoring study showed that apigenin, oleanolic acid, and ursolic acid found in basil are potential inhibitors of chymotrypsin-like protease found in coronavirus severe acute respiratory syndrome (SARS-CoV2) and could be investigated for possible treatment of the disease (Matondo et al., 2021).

\section{Toxicities}

Ocimum basilicum is a plant used in cooking for hundreds of years, and therefore no toxicological effects are expected. In the literature, few reports highlight toxic issues related to basil essential oil. Most of them report on the toxicity of some specific constituents of the oil. In general, basil essential oil and extracts obtained from the plant have few toxic effects when compared to other species of Ocimum, and vary depending on many variables such as plant variety, environment, climate, cultivation methods, among others, promoting different chemical compositions of essential oil (Sestili et al., 2018). Additionally, basil essential oil has been recognized as a safe compound by specialized agencies like the US FDA and the European Commission (Li \& Chang, 2016). In this sense, a study using a skin irritation model reported that basil essential oil does not present toxicity in human cells, suggesting that its topical use would not cause skin irritation (Stanojevic et al., 2019). In general, the studies found in the literature show that the essential oil of basil does not present cytotoxicity and can be considered safe in several applications in medicine and food.

\section{Conclusion}

Currently, due to the various effects of health promotion, the demand for natural products has increased. Thus, there is a growing interest in the pharmacological activity of basil essential oils. This review highlighted the main studies on the different essential oils of basil and gathered a lot of evidence about their full medicinal potential and the advantages of their use. The available literature on basil essential oil has several important pharmacological activities, such as antioxidant, antiviral, antimicrobial, anti-inflammatory, analgesic, and diuretic. Thus, the literature suggests that this essential oil has enormous pharmacological potential. However, further research must be carried out to increase knowledge about this plant and determine its effectiveness and use in clinical conditions, mainly due to variations in its composition.

\section{Acknowledgments}

This study was supported by grants from CAPES and CNPq, Brazil. 


\section{References}

Abdel-Kader, M. S., Soliman, G. A., Alqarni, M. H., Hamad, A. M., Foudah, A. I., \& Alqasoumi, S. I. (2019). Chemical composition and protective effect of Juniperus sabina L. essential oil against CCl4 induced hepatotoxicity. Saudi Pharmaceutical Journal, 27(7), 945-951. https://doi.org/10.1016/j.jsps.2019.07.003

Ahmad, K., Khalil, A. talha, Yusra, \& Somayya, R. (2016). Antifungal, phytotoxic and hemagglutination activity of methanolic extracts of Ocimum basilicum. Journal of Traditional Chinese Medicine, 36(6), 794-798. https://doi.org/10.1016/S0254-6272(17)30017-1

Ahmed, A. F., Attia, F. A. K., Liu, Z., Li, C., Wei, J., \& Kang, W. (2019). Antioxidant activity and total phenolic content of essential oils and extracts of sweet basil (Ocimum basilicum L.) plants. Food Science and Human Wellness, 8(3), 299-305. https://doi.org/10.1016/j.fshw.2019.07.004

Araújo Couto, H. G. S. de, Blank, A. F., Oliveira e Silva, A. M. de, Nogueira, P. C. de L., Arrigoni-Blank, M. de F., Nizio, D. A. de C., \& Pinto, J. A. de O. (2019). Essential oils of basil chemotypes: Major compounds, binary mixtures, and antioxidant activity. Food Chemistry, 293, 446-454. https://doi.org/10.1016/j.foodchem.2019.04.078

Bakkali, F., Averbeck, S., Averbeck, D., \& Idaomar, M. (2008). Biological effects of essential oils - A review. Food and Chemical Toxicology, 46(2), 446475. https://doi.org/10.1016/j.fct.2007.09.106

Beatović, D., Krstić-Milošević, D., Trifunović, S., Šiljegović, J., Glamočlija, J., Ristić, M., \& Jelačić, S. (2015). Chemical composition, antioxidant and antimicrobial activities of the essential oils of twelve Ocimum basilicum L. cultivars grown in Serbia. Records of Natural Products, 9(1), 62-75.

Berg, S. J. P. L. van den, Restani, P., Boersma, M. G., Delmulle, L., \& Rietjens, I. M. C. M. (2011). Levels of Genotoxic and Carcinogenic Ingredients in Plant Food Supplements and Associated Risk Assessment. Food and Nutrition Sciences, 02(09), 989-1010. https://doi.org/10.4236/fns.2011.29134

Bilal, A., Jahan, N., Ahmed, A., Bilal, S. N., Habib, S., \& Hajra, S. (2012). Phytochemical and pharmacological studies on ocimum basilicum linn - a review. Int. J. Curr. Res, 4, 73-83.

Bora, K. S., Arora, S., \& Shri, R. (2011). Role of Ocimum basilicum L. in prevention of ischemia and reperfusion-induced cerebral damage, and motor dysfunctions in mice brain. Journal of Ethnopharmacology, 137(3), 1360-1365. https://doi.org/10.1016/j.jep.2011.07.066

Bower, A., Marquez, S., \& de Mejia, E. G. (2016). The Health Benefits of Selected Culinary Herbs and Spices Found in the Traditional Mediterranean Diet. Critical Reviews in Food Science and Nutrition, 56(16), 2728-2746. https://doi.org/10.1080/10408398.2013.805713

Cardia, G. F. E., Silva-Comar, F. M. de S., Silva, E. L., Rocha, E. M. T. da, Comar, J. F., Silva-Filho, S. E., Zagotto, M., Uchida, N. S., Bersani-Amado, C. A., \& Cuman, R. K. N. (2021). Lavender (Lavandula officinalis) essential oil prevents acetaminophen-induced hepatotoxicity by decreasing oxidative stress and inflammatory response. Research, Society and Development, 10(3), e43410313461. https://doi.org/10.33448/rsd-v10i3.13461

Cardia, G. F. E., Silva-Filho, S. E., Silva, E. L., Uchida, N. S., Cavalcante, H. A. O., Cassarotti, L. L., Salvadego, V. E. C., Spironello, R. A., Bersani-Amado, C. A., \& Cuman, R. K. N. (2018). Effect of Lavender (Lavandula angustifolia) Essential Oil on Acute Inflammatory Response. Evidence-Based Complementary and Alternative Medicine, 2018, 1-10. https://doi.org/10.1155/2018/1413940

Ch, M., Naz, S., Sharif, A., Akram, M., \& Saeed, M. (2015). Biological and Pharmacological Properties of the Sweet Basil (Ocimum basilicum). British Journal of Pharmaceutical Research, 7(5), 330-339. https://doi.org/10.9734/BJPR/2015/16505

Chiang, L.-C., Ng, L.-T., Cheng, P.-W., Chiang, W., \& Lin, C.-C. (2005). Antiviral activities of extracts and selected pure constituents of Ocimum basilicum. Clinical and Experimental Pharmacology and Physiology, 32(10), 811-816. https://doi.org/10.1111/j.1440-1681.2005.04270.x

Clements, R., \& Treble, K. (1999). Plant Production. Glenormiston College, Institute of Land and Food Resources, the University ....

Duke, J. A. (2001). Handbook of Phytochemical Constituents of GRAS Herbs and Other Economic Plants. Herbal Reference Library.

Dwivedi, A. P., Kanikannan, L., \& Lakshmanan, S. (2015). AGNIKARMA- A Reference Manual for Ayurvedic Physicians- Information Directly Extracted from Approximately Three Thousand Year Old Literature. Ayurvedic, 2(2), 19. https://doi.org/10.14259/av.v2i2.176

Estrela, C. (2018). Metodologia científica: ciência, ensino, pesquisa. Artes Médicas.

Falowo, A. B., Mukumbo, F. E., Idamokoro, E. M., Afolayan, A. J., \& Muchenje, V. (2019). Phytochemical Constituents and Antioxidant Activity of Sweet Basil ( Ocimum basilicum L .) Essential Oil on Ground Beef from Boran and Nguni Cattle. International Journal of Food Science, 2019, 1-8. https://doi.org/10.1155/2019/2628747

Fathiazad, F., Matlobi, A., Khorrami, A., Hamedeyazdan, S., Soraya, H., Hammami, M., Maleki-Dizaji, N., \& Garjani, A. (2012). Phytochemical screening and evaluation of cardioprotective activity of ethanolic extract of Ocimum basilicum L. (basil) against isoproterenol induced myocardial infarction in rats. DARU Journal of Pharmaceutical Sciences, 20(1), 87. https://doi.org/10.1186/2008-2231-20-87

Gaio, I., Saggiorato, A. G., Treichel, H., Cichoski, A. J., Astolfi, V., Cardoso, R. I., Toniazzo, G., Valduga, E., Paroul, N., \& Cansian, R. L. (2015). Antibacterial activity of basil essential oil (Ocimum basilicum L.) in Italian-type sausage. Journal Für Verbraucherschutz Und Lebensmittelsicherheit, 10(4), 323-329. https://doi.org/10.1007/s00003-015-0936-x

Gautam, R., \& Jachak, S. M. (2009). Recent developments in anti-inflammatory natural products. Medicinal Research Reviews, 29(5), 767-820. https://doi.org/10.1002/med.20156

Gurav, T. P., Dholakia, B. B., \& Giri, A. P. (2021). A glance at the chemodiversity of Ocimum species: Trends, implications, and strategies for the quality and yield improvement of essential oil. Phytochemistry Reviews. https://doi.org/10.1007/s11101-021-09767-z

Hussain, A. I., Anwar, F., Hussain Sherazi, S. T., \& Przybylski, R. (2008). Chemical composition, antioxidant and antimicrobial activities of basil (Ocimum 
basilicum) essential oils depends on seasonal variations. Food Chemistry, 108(3), 986-995. https://doi.org/10.1016/j.foodchem.2007.12.010

Jugreet, B. S., \& Mahomoodally, M. F. (2020). Essential oils from 9 exotic and endemic medicinal plants from Mauritius shows in vitro antibacterial and antibiotic potentiating activities. South African Journal of Botany, 132, 355-362. https://doi.org/10.1016/j.sajb.2020.05.001

Karpiński, T. M. (2020). Essential Oils of Lamiaceae Family Plants as Antifungals. Biomolecules, 10(1), 103. https://doi.org/10.3390/biom10010103

Kaurinovic, B., Popovic, M., Vlaisavljevic, S., \& Trivic, S. (2011). Antioxidant Capacity of Ocimum basilicum L. and Origanum vulgare L. Extracts. Molecules, 16(9), 7401-7414. https://doi.org/10.3390/molecules16097401

Kaya, I., Yigit, N., \& Benli, M. (2008). Antimicrobial activity of various extracts of Ocimum basilicum 1. and observation of the inhibition effect on bacterial cells by use of scanning electron microscopy. African Journal of Traditional, Complementary and Alternative Medicines, 5(4), 363. https://doi.org/10.4314/ajtcam.v5i4.31291

Kiferle, C., Ascrizzi, R., Martinelli, M., Gonzali, S., Mariotti, L., Pistelli, L., Flamini, G., \& Perata, P. (2019). Effect of Iodine treatments on Ocimum basilicum L.: Biofortification, phenolics production and essential oil composition. PLOS ONE, 14(12), e0226559. https://doi.org/10.1371/journal.pone.0226559

Kocić-Tanackov, S., Dimić, G., Đerić, N., Mojović, L., Tomović, V., Šojić, B., Đukić-Vuković, A., \& Pejin, J. (2020). Growth control of molds isolated from smoked fermented sausages using basil and caraway essential oils, in vitro and in vivo. LWT, 123, 109095. https://doi.org/10.1016/j.lwt.2020.109095

Koroch, A. R., Simon, J. E., \& Juliani, H. R. (2017). Essential oil composition of purple basils, their reverted green varieties (Ocimum basilicum) and their associated biological activity. Industrial Crops and Products, 107, 526-530. https://doi.org/10.1016/j.indcrop.2017.04.066

Li, Q. X., \& Chang, C. . (2016). Basil (Ocimum basilicum L.) oils. (Preedy V.R. (ed.); Essential). Elsevier Inc.

Licon, C. C., Moro, A., Librán, C. M., Molina, A. M., Zalacain, A., Berruga, M. I., \& Carmona, M. (2020). Volatile Transference and Antimicrobial Activity of Cheeses Made with Ewes' Milk Fortified with Essential Oils. Foods, 9(1), 35. https://doi.org/10.3390/foods9010035

Marco, A., Santos, S., Caetano, J., Pintado, M., Vieira, E., \& Moreira, P. R. (2020). Basil essential oil as an alternative to commercial biocides against fungi associated with black stains in mural painting. Building and Environment, 167, 106459. https://doi.org/10.1016/j.buildenv.2019.106459

Marotti, M., Piccaglia, R., \& Giovanelli, E. (1996). Differences in essential oil composition of basil (Ocimum basilicum L.) Italian cultivars related to morphological characteristics. Journal of Agricultural and Food Chemistry, 44(12), 3926-3929.

Matondo, A., Kilembe, J. T., Ngoyi, E. M., Kabengele, C. N., Kasiama, G. N., Lengbiye, E. M., Mbadiko, C. M., Inkoto, C. L., Bongo, G. N., Gbolo, B. Z., Falanga, C. M., Mwanangombo, D. T., Opota, D. O., Tshibangu, D. S. T., Tshilanda, D. D., Ngbolua, K.-N., \& Mpiana, P. T. (2021). Oleanolic Acid, Ursolic Acid and Apigenin from Ocimum basilicum as Potential Inhibitors of the SARS-CoV-2 Main Protease: A Molecular Docking Study. International Journal of Pathogen Research, 1-16. https://doi.org/10.9734/ijpr/2021/v6i230156

Miao, Q., Zhao, L., Wang, Y., Hao, F., Sun, P., He, P., Liu, Y., Huang, J., Liu, X., Liu, X., Deng, G., Li, H., Li, L., Tang, Y., Wang, L., Feng, M., \& Jia, W. (2020). Microbial metabolomics and network analysis reveal fungistatic effect of basil (Ocimum basilicum) oil on Candida albicans. Journal of Ethnopharmacology, 260,113002. https://doi.org/10.1016/j.jep.2020.113002

Nazir, S., Jan, H., Tungmunnithum, D., Drouet, S., Zia, M., Hano, C., \& Abbasi, B. H. (2020). Callus Culture of Thai Basil Is an Effective Biological System for the Production of Antioxidants. Molecules, 25(20), 4859. https://doi.org/10.3390/molecules25204859

Opalchenova, G., \& Obreshkova, D. (2003). Comparative studies on the activity of basil—an essential oil from Ocimum basilicum L.—against multidrug resistant clinical isolates of the genera Staphylococcus, Enterococcus and Pseudomonas by using different test methods. Journal of Microbiological Methods, 54(1), 105-110. https://doi.org/10.1016/S0167-7012(03)00012-5

Pandey, V., Patel, A., \& Patra, D. D. (2016). Integrated nutrient regimes ameliorate crop productivity, nutritive value, antioxidant activity and volatiles in basil (Ocimum basilicum L.). Industrial Crops and Products, 87, 124-131.

Paton, A., Harley, R. M., \& Harley, M. M. (1999). Basil: the genus Ocimum. Edits., R. Hiltunen and Y. Holm, Harwood Academic publishers.

Pawar, N., Gandhi, K., Purohit, A., Arora, S., \& Singh, R. R. B. (2014). Effect of added herb extracts on oxidative stability of ghee (butter oil) during accelerated oxidation condition. Journal of Food Science and Technology, 51(10), 2727-2733.

Putievsky, E., Paton, A., Lewinsohn, E., Ravid, U., Haimovich, D., Katzir, I., Saadi, D., \& Dudai, N. (1999). Crossability and relationship between morphological and chemical varieties of Ocimum basilicum L. Journal of Herbs, Spices \& Medicinal Plants, 6(3), 11-24.

Reichling, J., Schnitzler, P., Suschke, U., \& Saller, R. (2009). Essential Oils of Aromatic Plants with Antibacterial, Antifungal, Antiviral, and Cytotoxic Properties - an Overview. Complementary Medicine Research, 16(2), 79-90. https://doi.org/10.1159/000207196

Runyoro, D., Ngassapa, O., Vagionas, K., Aligiannis, N., Graikou, K., \& Chinou, I. (2010). Chemical composition and antimicrobial activity of the essential oils of four Ocimum species growing in Tanzania. Food Chemistry, 119(1), 311-316. https://doi.org/10.1016/j.foodchem.2009.06.028

Ryu, S. Y., Lee, C.-K., Lee, C. O., Kim, H. S., \& Zee, O. P. (1992). Antiviral triterpenes fromPrunella vulgaris. Archives of Pharmacal Research, 15(3), 242245. https://doi.org/10.1007/BF02974063

Sahoo, Y., Pattnaik, S. K., \& Chand, P. K. (1997). In vitro clonal propagation of an aromatic medicinal herb Ocimum basilicum L. (sweet basil) by axillary shoot proliferation. In Vitro Cellular \& Developmental Biology - Plant, 33(4), 293-296. https://doi.org/10.1007/s11627-997-0053-3

Sant'Anna Ramos Vosgerau, D., \& Paulin Romanowski, J. (2014). Estudos de revisão: implicações conceituais e metodológicas. Revista Diálogo Educacional, 14(41), 165. https://doi.org/10.7213/dialogo.educ.14.041.DS08 
Sestili, P., Ismail, T., Calcabrini, C., Guescini, M., Catanzaro, E., Turrini, E., Layla, A., Akhtar, S., \& Fimognari, C. (2018). The potential effects of Ocimum basilicum on health: a review of pharmacological and toxicological studies. Expert Opinion on Drug Metabolism \& Toxicology, 14(7), 679-692. https://doi.org/10.1080/17425255.2018.1484450

Singh, D., \& Chaudhuri, P. K. (2018). A review on phytochemical and pharmacological properties of Holy basil (Ocimum sanctum L.). Industrial Crops and Products, 118, 367-382. https://doi.org/10.1016/j.indcrop.2018.03.048

Singh, S., Majumdar, D. K., \& Rehan, H. M. S. (1996). Evaluation of anti-inflammatory potential of fixed oil of Ocimum sanctum (Holybasil) and its possible mechanism of action. Journal of Ethnopharmacology, 54(1), 19-26. https://doi.org/10.1016/0378-8741(96)83992-4

Stanojevic, L. P., Marjanovic-Balaban, Z. R., Kalaba, V. D., Stanojevic, J. S., Cvetkovic, D. J., \& Cakic, M. D. (2017). Chemical Composition, Antioxidant and Antimicrobial Activity of Basil ( Ocimum basilicum L.) Essential Oil. Journal of Essential Oil Bearing Plants, 20(6), 1557-1569. https://doi.org/10.1080/0972060X.2017.1401963

Stanojevic, L. P., Stanojevic, J. S., Savic, V. L., Cvetkovic, D. J., Kolarevic, A., Marjanovic-Balaban, Z., \& Nikolic, L. B. (2019). Peppermint and Basil Essential Oils: Chemical Composition, in vitro Antioxidant Activity and in vivo Estimation of Skin Irritation. Journal of Essential Oil Bearing Plants, 22(4), 979-993. https://doi.org/10.1080/0972060X.2019.1661793

Sunčica, K. T., Gordana, D., Jelena, L., Ilija, T., \& Danijela, T. (2011). Antifungal activities of basil (Ocimum basilicum L.) extract on Fusarium species. African Journal of Biotechnology, 10(50), 10188-10195. https://doi.org/10.5897/AJB11.1330

Sundararajan, B., Moola, A. K., Vivek, K., \& Kumari, B. D. R. (2018). Formulation of nanoemulsion from leaves essential oil of Ocimum basilicum L. and its antibacterial, antioxidant and larvicidal activities (Culex quinquefasciatus). Microbial Pathogenesis, 125, 475-485. https://doi.org/10.1016/j.micpath.2018.10.017

Tavallali, V., Kiani, M., \& Hojati, S. (2019). Iron nano-complexes and iron chelate improve biological activities of sweet basil (Ocimum basilicum L.). Plant Physiology and Biochemistry, 144, 445-454. https://doi.org/10.1016/j.plaphy.2019.10.021

Thomford, N. E., Senthebane, D. A., Rowe, A., Munro, D., Seele, P., Maroyi, A., \& Dzobo, K. (2018). Natural Products for Drug Discovery in the 21st Century: Innovations for Novel Drug Discovery. International Journal of Molecular Sciences, 19(6). https://doi.org/10.3390/ijms 19061578

Topalov, V. D., \& Topalov, V. (1962). Essential oil and medicinal plants. Hr. G. Danov Press, Plovdiv, Bulgaria.

Umar, A., Imam, G., Yimin, W., Kerim, P., Tohti, I., Berké, B., \& Moore, N. (2010). Antihypertensive effects of Ocimum basilicum L. (OBL) on blood pressure in renovascular hypertensive rats. Hypertension Research, 33(7), 727-730. https://doi.org/10.1038/hr.2010.64

Uritu, C. M., Mihai, C. T., Stanciu, G.-D., Dodi, G., Alexa-Stratulat, T., Luca, A., Leon-Constantin, M.-M., Stefanescu, R., Bild, V., Melnic, S., \& Tamba, B. I. (2018). Medicinal Plants of the Family Lamiaceae in Pain Therapy: A Review. Pain Research and Management, 2018 , 1-44. https://doi.org/10.1155/2018/7801543

Yap, P. S. X., Yiap, B. C., Ping, H. C., \& Lim, S. H. E. (2014). Essential Oils, A New Horizon in Combating Bacterial Antibiotic Resistance. The Open Microbiology Journal, 8(1), 6-14. https://doi.org/10.2174/1874285801408010006

Yuan, G., Chen, X., \& Li, D. (2016). Chitosan films and coatings containing essential oils: The antioxidant and antimicrobial activity, and application in food systems. Food Research International, 89, 117-128.

Złotek, U., Michalak-Majewska, M., \& Szymanowska, U. (2016). Effect of jasmonic acid elicitation on the yield, chemical composition, and antioxidant and anti-inflammatory properties of essential oil of lettuce leaf basil ( Ocimum basilicum L.). Food Chemistry, 213, 1-7. https://doi.org/10.1016/j.foodchem.2016.06.052 